\author{
Mateusz Kuczyk \\ Piotr Jędrzejewski \\ Pawel Zaluski \\ Politechnika Gdańska
}

\title{
Evaluation of suspended rail vehicle movement parameters
}

\section{Ocena parametrów ruchowych pojazdu kolei podwieszanej}

\begin{abstract}
This publication is devoted to the evaluation of the movement parameters of the concept suspended monorail vehicle which was conducted on a basis of its traction characteristic and dynamic capabilities. Firstly, the construction of the proposed vehicle was briefly described along with the specification of the most important design assumptions. Subsequently, the focus was put on the methodology and the very plotting of the vehicle's traction characteristic, as well as the process of its acceleration as a function of speed. Finally, the braking system was assessed by determining the average braking deceleration depending on its type. This article is based on authors' master thesis: ,, The concept of suspended railway engine wagon”, conducted on Mechanical Engineering Faculty of Gdansk University of Technology.
\end{abstract}

Niniejsza publikacja została poświęcona ocenie parametrów ruchowych koncepcyjnego pojazdu kolei podwieszanej, którq dokonano $w$ oparciu o jego charakterystykę trakcyjnq oraz możliwości dynamiczne. W pierwszej kolejności skrótowo opisano konstrukcje proponowanego pojazdu wraz z wyszczególnieniem najważniejszych założeń projektowych. Następnie skupiono się na metodyce oraz samym wykreśleniu charakterystyki trakcyjnej pojazdu, jak również przebiegu jego przyspieszenia w funkcji prędkości. Na koniec poddano ocenie uklad hamulcowy poprzez wyznaczenie średniego opóźnienia hamowania w zależności od jego rodzaju. Artykut ten powstat na podstawie pracy dyplomowej pt. „Koncepcja wagonu silnikowego kolei podwieszanej", na wydziale Mechanicznym Politechniki Gdańskiej.

Keywords: rail vehicle, traction drive, hydrogen powered

Slowa kluczowe: pojazd szynowy, napęd trakcyjny, zasilanie wodorem

\section{INTRODUCTION}

Suspended railway, belonging to the group of monorails, should be treated as a cheaper alternative to the metro in medium-sized urban agglomerations. Vehicles of this type are characterised by: full independence from traffic, the possibility of easy automation and a relatively short construction time of the necessary infrastructure which takes up only a small area of ground. Currently, there are three suspended monorail systems in the world that are used in urban transportation, namely: Schwebebahn in the German city of Wuppertal and located in the metropolitan area of Tokyo in Japan: Shonan and Chiba monorail. More on the existing solutions can be found in the earlier publication of the authors [1].

Due to the low popularity of suspended monorail, there are only a few studies in the professional literature concerning this type of vehicles. Moreover, those publications refer only to the general description of solutions and in the same time they concentrate on comparison between different types of monorails. Excellent example of such literature is [2]. In the field of more specialized studies, there could be distinguished for example [3], which refers to vehicle dynamic issues. Technical papers that concentrate on monorail traction calculations, actually don't exist. Due to the fact that authors' vehicle concept is very different from standard suspended monorail vehicles

\section{WSTĘP}

Kolej podwieszaną zaliczającą się do grupy kolei jednoszynowych należy traktować, jako tańszą alternatywę dla metra w średniej wielkości aglomeracjach miejskich. Pojazdy tego typu charakteryzują się: całkowitą niezależnością od ruchu ulicznego, możliwością łatwej automatyzacji czy stosunkowo krótkim czasem budowy niezbędnej infrastruktury, która zajmuje jedynie nieznaczną powierzchnię gruntu. Aktualnie na świecie można wyróżnić trzy systemy kolei podwieszanej pełniące funkcję transportu miejskiego, to jest: Schwebebahn w niemieckich mieście Wuppertal oraz znajdujące sie w obszarze aglomeracyjnym Tokyo w Japonii: Shonan i Chiba monorail. Więcej na temat istniejących rozwiązań można znaleźć we wcześniejszej publikacji autorów [1].

Ze względu na małe rozpowszechnienie kolei podwieszanej, występują tylko nieliczne opracowania w literaturze fachowej dotyczące tego typu pojazdów. Ponadto prezentują one dość ogólny przegląd stosowanych rozwiązań technicznych jednocześnie porównując różne typy kolei jednoszynowych. Dobrym przykładem opracowań tego typ jest [2]. Jeżeli chodzi o pozycje bardziej szczegółowe można wyróżnić chociażby [3], która skupia się na zagadnieniach dynamiki pojazdu. Z kolei literatura poświęcona zagadnieniom obliczeń trakcyjnych w ujęciu kolei podwieszanych praktycznie nie istnieje. Jednak zważywszy na fakt, że 
(generally not only suspended but all monorail vehicles), in the course of writing this paper, the authors used mainly studies on traction calculations for traditional rail vehicles, of course wherever it is necessary adapting them to this particular solution. One of the most helpful publications of this kind was [4].

\section{VEHICLE'S MOVEMENT ANALYSIS}

The vehicle proposed by the authors (Fig. 1) is a threesection, bidirectional, suspended electric multiple unit.

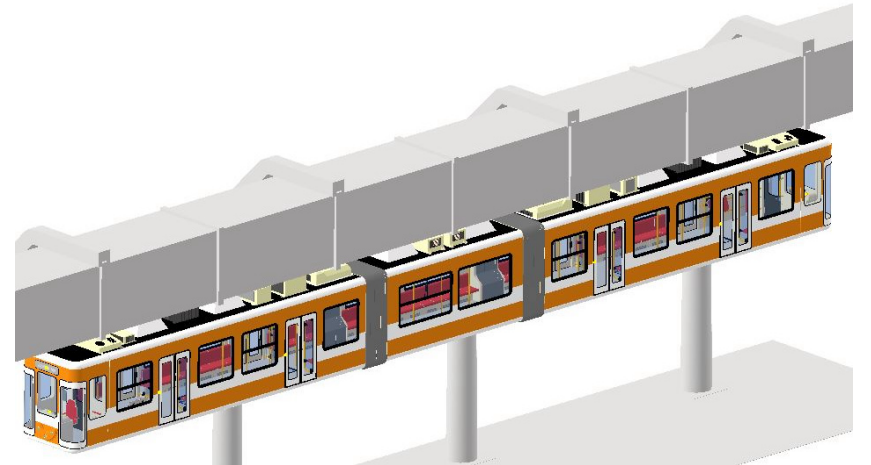

Fig. 1. Authors' suspended electric multiple unit [5]

Rys. 1. Podwieszany elektryczny zespół trakcyjny autorów [5]

The vehicle is suspended below a closed guideway beam where, along a pair of steel rails, move three bogies similar in their design to conventional rail bogies (Fig. 2). The electric energy is supplied to the rolling stock from an additional current rail through a bottom-running current collector. The electric circuit is closed by wheel-rail contact.

Table 1 Technical specification of suspended EMU Tabela 1 Wybrane dane techniczne podwieszanego EZT

\begin{tabular}{|l|c|c|}
\hline Feature / Cecha & $\begin{array}{c}\text { Unit / } \\
\text { Jednostka }\end{array}$ & $\begin{array}{c}\text { Value / } \\
\text { Wartość }\end{array}$ \\
\hline $\begin{array}{l}\text { Overall length / Długość } \\
\text { całkowita }\end{array}$ & $\mathrm{mm}$ & 32580 \\
\hline $\begin{array}{l}\text { Width of the vehcile car body / } \\
\text { Szerokość pudła wagonu }\end{array}$ & $\mathrm{mm}$ & 2500 \\
\hline $\begin{array}{l}\text { Height of the vehicle car body / } \\
\text { Wysokość pudła wagonu }\end{array}$ & $\mathrm{mm}$ & 3025 \\
\hline $\begin{array}{l}\text { Empty carriage mass / Masa } \\
\text { własna pojazdu }\end{array}$ & $\mathrm{kg}$ & 43611 \\
\hline $\begin{array}{l}\text { Maximum vehicle mass / } \\
\text { Dopuszczalna masa całkowita }\end{array}$ & $\mathrm{kg}$ & 71811 \\
\hline $\begin{array}{l}\text { Total capacity / Całkowita } \\
\text { liczba miejsc }\end{array}$ & - & 376 \\
\hline $\begin{array}{l}\text { Seating capacity / Liczba miejsc } \\
\text { siedzących }\end{array}$ & - & 80 \\
\hline $\begin{array}{l}\text { Standing capacity / Liczba } \\
\text { miejsc stojących }\end{array}$ & - & 296 \\
\hline $\begin{array}{l}\text { Power supply voltage DC / } \\
\text { Napięcie zasilania DC }\end{array}$ & $\mathrm{V}$ & 600 \\
\hline $\begin{array}{l}\text { Total vehicle power / Moc } \\
\text { całkowita }\end{array}$ & $\mathrm{kW}$ & 840 \\
\hline $\begin{array}{l}\text { Maximum speed / Prędkość } \\
\text { maksymalna }\end{array}$ & $\mathrm{km} / \mathrm{h}$ & 70 \\
\hline Axle arrangement / Układ osi & - & $1 \mathrm{~A}^{\prime}+1 \mathrm{~A}+1 \mathrm{~A}$ ' \\
\hline Wheel diameter / Średnica kół & $\mathrm{mm}$ & $700 / 750$ \\
\hline $\begin{array}{l}\text { Bogie centre distance / Rozstaw } \\
\text { czopów skrętu }\end{array}$ & $\mathrm{mm}$ & 10680 \\
\hline Wheelbase / Baza wózka & $\mathrm{mm}$ & 1600 \\
\hline
\end{tabular}

proponowane przez autorów rozwiązanie, w znacznej mierze odbiega od standardowych pojazdów kolei podwieszanej (czy ogólniej jednoszynowej), autorzy przeważnie skupiali się na publikacjach poświęconych tradycyjnym pojazdom szynowych, oczywiście tam gdzie to konieczne dostosowując wzory do specyficznych zagadnień kolei podwieszanej. Szczególnie istotna i pomocna w tym zakresie okazała się [4]

\section{ANALIZA RUCHOWA POJAZDU}

Proponowany przez autorów pojazd (rys. 1) jest trójczłonowym, dwukierunkowym, podwieszanym elektrycznym zespołem trakcyjnym. Pojazd zawieszony jest poniżej zamkniętej belki jezdnej, w której poruszają się, po parze stalowych szyn, trzy wózki podobne w swojej konstrukcji do konwencjonalnych wózków kolejowych (rys. 2). Energia elektryczna zasilająca skład jest pobierana $\mathrm{z}$ dodatkowej szyny prądowej, przez odbierak prądu o ślizgu dolnym. Sieć powrotną stanowią zestawy kołowe oraz szyny.

Do najważniejszych założeń projektowych, mających decydujący wpływ na ostateczny kształt pojazdu, należy zaliczyć:

- prędkość maksymalną przekraczającą $50 \mathrm{~km} / \mathrm{h}$;

- możliwość pokonywania toru o znacznym kącie nachylenia;

- możliwie dużą pojemność całkowitą.

Dodatkowo miejskie przeznaczenie pojazdu wymusza dążenie do minimalizacji emisji dźwięku i drgań do otoczenia jak również umożliwienia pokonywania torów o małym promieniu krzywizny. Wymagania te spełniono poprzez odpowiednią budowę wózków: krótką bazę, smarowanie obrzeży kół czy niską masę nieusprężynowaną. Wybrane parametry techniczne składu zostały zestawione w tabeli 1 [5], gdzie celowo nie uwzględniono parametrów ruchowych takich jak przyspieszenie czy opóźnienie.

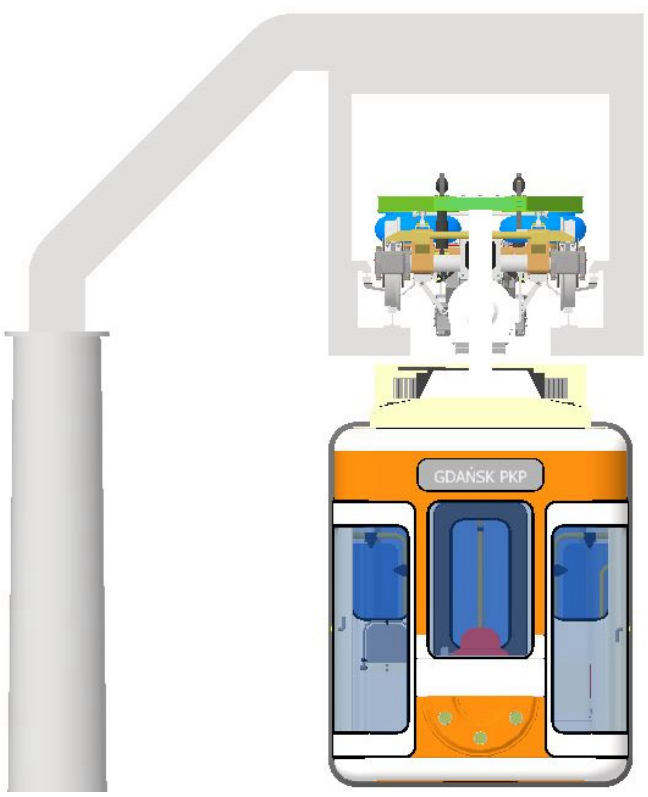

Fig. 2. Concept of the suspended railway system [5] Rys. 2. Proponowany system kolei podwieszanej [5] 
The most important assumptions that had the biggest influence on the final vehicle's design are:

- maximum speed exceeding $50 \mathrm{~km} / \mathrm{h}$;

- ability to run on a track with significant slope angle;

- as high total capacity as possible.

In addition, the urban designation of the vehicle forces a need to minimize sound emission and vibrations to the surroundings, as well as to enable it to run in a curve with a small turning radius. These requirements were fulfilled by a suitable bogie design: short wheelbase, lubrication of the wheel flanges and low unsprung mass. Selected technical data of the rolling stock are presented in Table 1 [5], where the parameters regarding acceleration and braking are omitted on purpose.

Visible in the table untypical axle arrangement is dictated by the need to place in the bogie a gearbox with a high gear ratio and a relatively high-powered motor which made it impossible to drive simultaneously both wheelsets. Detailed description of the vehicle's design will be a subject of another publication and in this one authors focus only on propulsion and braking systems and more specifically on the parameters obtained by them.

\subsection{Propulsion system}

The vehicle is equipped with three asynchronous, squirrel-cage motors (DKLBZ 0910-04 made by VEM which technical data originated from [5] were used in the calculations), powered individually from traction inverters that convert direct current supplied to the vehicle into alternating current with adjustable parameters (e.g. frequency or voltage values). Every motor is connected via a flexible coupling with a twostage bevel-helical gear unit. Finally, the torque is transferred on a single wheelset by a pair of link couplings connected with each other by a hollow shaft. Both the motor and the gearbox are suspended in the frame of the bogie. In order to plot the traction characteristic of the vehicle, the following quantities are necessary (a lack of numerical value means that the value of the given parameter is not a constant during the calculations):

- total number of axles $-\mathrm{c}=6$;

- total number of driven axles $-b=3$;

- total number of vehicle's motors $-\mathrm{s}=3$;

- total efficiency of the gearbox $-\eta_{\mathrm{c}}=0.96$;

- pressure of powered wheelsets on the track $-Q_{n}$ $[\mathrm{N}]$ (assuming an even distribution of the vehicle weight between all wheelsets);

- vehicle weight - Q [kN];

- maximal total vehicle's mass - $71811 \mathrm{~kg}$;

- angle of inclination $-\alpha\left[^{\circ}\right]$;

- number of cars in a multiple unit $-\mathrm{z}=2$;

- number of axles $-\mathrm{n}=6$;
Widoczny w tabeli nietypowy układ osi jest podyktowany koniecznością zabudowy w wózku przekładni o dużym przełożeniu i silnika o stosunkowo dużej mocy, co skutecznie uniemożliwia jednoczesne napędzanie obu zestawów kołowych. Szczegółowa budowa pojazdu będzie tematem oddzielnej publikacji, a w niniejszym artykule autorzy skupią się wyłącznie na układzie napędowym i hamulcowym, a dokładniej na uzyskanych dzięki nim parametrach.

\subsection{Układ napędowy}

Pojazd został wyposażony $\mathrm{w}$ trzy klatkowe silniki asynchroniczne (DKLBZ 0910-04 firmy VEM, których dane techniczne wykorzystane $w$ obliczeniach pochodzą z [5]), zasilane indywidualnie z falowników trakcyjnych zamieniających doprowadzony do pojazdu prąd stały na prąd zmienny o regulowalnych parametrach (np. częstotliwości czy wartości napięcia). Każdy silnik połączony jest przy pomocy sprzęgła podatnego z dwustopniowa, stożkowo-walcową przekładnią mechaniczną. Na koniec moment napędowy przenoszony jest na pojedynczy zestaw kołowy, poprzez parę sprzęgieł cięgnowych połączonych ze soba wałem drążonym. Zarówno silnik jak i przekładnia zostały zawieszone w ramie wózka. W celu wykreślenia charakterystyki trakcyjnej pojazdu niezbędne sa następujące wielkości (brak wartości liczbowej oznacza, że wartość danego parametru nie jest stała w czasie obliczeń):

- całkowita liczba osi $-\mathrm{c}=6$;

- całkowita liczba osi napędnych - $b=3$;

- całkowita liczba silników pojazdu $-\mathrm{s}=3$;

- całkowita sprawność przekładni mechanicznej $\eta_{\mathrm{c}}=0,96$;

- ciężar napędny pojazdu $-\mathrm{Q}_{\mathrm{n}}[\mathrm{N}]$ (przy założeniu równomiernego rozkładu masy pojazdu pomiędzy wszystkie zestawy kołowe);

- ciężar pojazdu - Q [kN];

- dopuszczalna, całkowita masa pojazdu $\mathrm{m}=71811 \mathrm{~kg}$;

- $\quad k a ̨ t$ nachylenia wzniesienia $-\alpha\left[^{\circ}\right]$;

- liczba wagonów w zespole trakcyjnym $-\mathrm{z}=2$;

- liczba osi zespołu trakcyjnego $-\mathrm{n}=6$;

- moc silnika - $\mathrm{N}_{\mathrm{sil}}=280000 \mathrm{~W}$;

- moment obrotowy silnika $-\mathrm{M}_{\text {sil }}[\mathrm{Nm}]$;

- prędkość ruchu pojazdu - v [m/s];

- przełożenie przekładni mechanicznej - $\mathrm{i}=8$ (przełożenie to wynika $\mathrm{z}$ założonej prędkości maksymalnej pojazdu oraz średnicy tocznej jego kół);

- przyspieszenie ziemskie $-\mathrm{g}=9,81 \mathrm{~m} / \mathrm{s}^{2}$;

- $\quad$ statyczny współczynnik przyczepności $-\Psi_{0}=0,33$ (zgodnie z $[6,7]$ wartość ta jest powszechnie przyjmowana w kolejnictwie dla szyn suchych, a wykorzystanie jej w charakterystyce pojazdu jest uzasadnione umiejscowieniem szyn w zamkniętej belce jezdnej);

- średnica toczna nowego koła $-\mathrm{D}_{\mathrm{K}}=750 \mathrm{~mm}$; 
- $\quad$ motor power $-\mathrm{N}_{\mathrm{sil}}=280000 \mathrm{~W}$;

- motor torque $-\mathrm{M}_{\text {sil }}[\mathrm{Nm}]$;

- vehicle speed $-\mathrm{v}[\mathrm{m} / \mathrm{s}]$;

- mechanical transmission gear ratio $-\mathrm{i}=8$ (this ratio results from the assumed maximum speed of the vehicle and the rolling diameter of its wheels);

- gravitational acceleration $-\mathrm{g}=9.81 \mathrm{~m} / \mathrm{s}^{2}$;

- static adhesion coefficient $-\Psi_{0}=0.33$ (according to $[6,7]$ the value is commonly adopted in railways for dry rails and its use in the vehicle characteristics justifies the location of the rails in a closed guideway beam);

- rolling diameter of the new wheel $-\mathrm{D}_{\mathrm{K}}=750 \mathrm{~mm}$;

- rotational mass coefficient $-\gamma=1.15$ (according to [4] it is an approximate value for railcars).

The basic determinant of the assessment of the vehicle's movement parameters is its traction characteristic (Fig. 3) showing a graph of: motion resistance, adhesion forces and resultant traction force as a function of speed.

The vehicle's motion resistance (W) is a sum of the basic resistance (the so-called own resistance) which can be divided into component resistances: wheel motion along the rail, resistance coming from bearings in wheelsets' axleboxes, caused by energy dissipation in the trackbed and in the vehicle suspension; and additional resistances such as climbing or curve resistance. The first of the aforementioned was determined on a basis of the following empirical relationship: [4]

$$
\begin{aligned}
& W_{z a s}=(0,65+0,054 \cdot v) \cdot Q+ \\
& +147 \cdot n+(2,7+z) \cdot 1,271 \cdot v^{2}
\end{aligned}
$$

This formula was developed by the Railway Research Institute IK for railway multiple units. Due to the unusual configuration of the designed vehicle, the authors decided that it can be compared to a two-section, three-bogie (with a central Jacobs bogie), a railway EMU and for such carried out the calculations. As for the additional resistance, it was decided to take into account only the climbing resistance, in accordance with:

$$
W_{i}=Q \cdot \sin (\alpha)
$$

The adhesion forces between rail and wheels are the practical limitation of traction forces. Exceeding this limit value results in increase in slip up to $100 \%$. The limit value of adhesion forces was calculated in accordance with: [7]

$$
F_{\Psi}=Q_{n} \cdot \Psi \cdot \cos (\alpha)=m \cdot g \cdot \frac{b}{c} \cdot \Psi \cdot \cos (\alpha)
$$

The crucial impact on the value of traction forces has the value of the adhesion coefficient which change as a function of speed was determined according to the Parodi formula: $[6,7]$
- współczynnik mas wirujących - $\gamma=1,15$ (według [4] jest to przybliżona wartość dla wagonów silnikowych).

Podstawowym wyznacznikiem oceny parametrów ruchowych pojazdu jest jego charakterystyka trakcyjna (rys. 3), ukazująca przebieg: oporów ruchu, sił przyczepności oraz wypadkowej siły trakcyjnej w funkcji prędkości.

Opory ruchu pojazdu (W) są sumą oporu zasadniczego (tzw. oporu własnego), który można podzielić na opory składowe: ruchu koła po szynie, oporu pochodzącego od łożysk w maźnicach zestawów kołowych, spowodowanego dyssypacją energii $\mathrm{w}$ podtorzu i w zawieszeniu pojazdu; oraz opory dodatkowe takie jak opór wzniesienia czy zakrętu. Opór własny pojazdu został wyznaczony na podstawie poniższej zależności empirycznej: [4]

$$
\begin{aligned}
& W_{z a s}=(0,65+0,054 \cdot v) \cdot Q+ \\
& +147 \cdot n+(2,7+z) \cdot 1,271 \cdot v^{2}
\end{aligned}
$$

Wzór ten został opracowany przez Instytut Kolejnictwa dla kolejowych zespołów trakcyjnych. W związku z nietypową konfiguracją zaprojektowanego pojazdu, autorzy uznali, że można go przyrównać do dwuczłonowego, trójwózkowego (z środkowym wózkiem Jacobsa), kolejowego EZT i dla takiego przeprowadzić obliczenia. $Z$ oporów dodatkowych zdecydowano się na uwzględnienie wyłącznie oporu wzniesienia, zgodnie z:

$$
W_{i}=Q \cdot \sin (\alpha)
$$

Siły przyczepności występujące pomiędzy szyną a kołami, stanowią praktyczne ograniczenie sił trakcyjnych. Przekroczenie wartości granicznej skutkuje stopniowym wzrostem poślizgu aż do $100 \%$. Graniczna wartość sił przyczepności została obliczona zgodnie z: [7]

$$
F_{\Psi}=Q_{n} \cdot \Psi \cdot \cos (\alpha)=m \cdot g \cdot \frac{b}{c} \cdot \Psi \cdot \cos (\alpha)
$$

Decydujący wpływ na wartość sił przyczepności ma wielkość współczynnika przyczepności, którego przebieg w funkcji prędkości wyznaczono według wzoru Parodiego: $[6,7]$

$$
\Psi=\frac{\Psi_{0}}{1+0,036 \cdot v}
$$

Do wyznaczenia samej siły trakcyjnej posłużono się zależnością: [7]

$$
F=\frac{2 \cdot s \cdot M_{s i l} \cdot i_{a} \cdot \eta_{c}}{D_{K}}
$$

Zastosowanie przetwornic częstotliwościowych do zasilania silników trakcyjnych pojazdu pozwala na praktycznie dowolne kształtowanie jego charakterystyki trakcyjnej. Na wyznaczonej krzywej granicznej sił pociagowych (linia czerwona na rys. 3), można wyróżnić dwa obszary pracy: ze stałym momentem (do częstotliwości $55 \mathrm{~Hz}$, odpowiadającej prędkości $30 \mathrm{~km} / \mathrm{h}$ ) i ze stałą mocą. W drugim przypadku moment obrotowy silnika $\mathrm{w}$ danej chwili czasu wyznaczono według: [8] 


$$
\Psi=\frac{\Psi_{0}}{1+0,036 \cdot v}
$$

The following equation was used to determine the traction force itself: [7]

$$
F=\frac{2 \cdot s \cdot M_{s i l} \cdot i_{a} \cdot \eta_{c}}{D_{K}}
$$

The use of frequency converters to supply the vehicle's traction motors allows for practically any shaping of its traction characteristic. On the determined boundary curve of tractive forces (red line in Fig. 3), two areas of operation can be distinguished: with constant torque (up to the frequency of $55 \mathrm{~Hz}$, corresponding to a speed of $30 \mathrm{~km} / \mathrm{h}$ ) and with constant power. In the second case, the engine torque at a given moment of time was determined according to: [8]

$$
M_{\text {sil }}=\frac{N_{\text {sil }}}{\omega_{1}}
$$

It is possible to eliminate the initial working area with a constant torque which makes it easier to start the rolling stock with a high load. In this case, the amount of torque decreases exponentially, as the motor speed (supply frequency) increases, from its maximum value.

The determined characteristic proves the fulfilment of one of the initial design assumptions, that is, running on a track with a significant slope angle $p$ [\%]. This was achieved thanks to the high value of traction and adhesion forces. The first of them were obtained as a result of the use of high-power motors $(280 \mathrm{~kW})$ and a mechanical transmission with a high ratio. On the other hand, the latter are the result of the high ratio of driving axles to trailing axles (high value pressure of powered axles against rails) and the protection of the rails against weather conditions in the guideway beam and the resulting relatively high value of the static coefficient of adhesion.

The aforementioned characteristic was determined for the fully loaded vehicle. In operational practice, this type of situation is extremely rare, and most of the courses take place with only half of the total vehicle capacity. Along with the decrease in the total weight of the vehicle, the adhesion forces and motion resistance also decrease, which in total translates into a slight increase in the value of the maximum track inclination. In addition, there is then a significant surplus of traction forces in relation to the adhesion forces, and therefore, in order to prevent excessive skid of the wheelsets, an anti-skid system was used.

An important movement parameter of the public transport rolling stock is its appropriate dynamics, necessary for a high number of starts and braking. In order to assess the dynamic capabilities of the vehicle, the acceleration value was used, determined according to: [4]

$$
a=\frac{1}{\gamma \cdot m} \cdot\left(\frac{s \cdot N_{s i l} \cdot \eta_{c}}{v}-W\right)
$$

$$
M_{\text {sil }}=\frac{N_{\text {sil }}}{\omega_{1}}
$$

Istnieje możliwość wyelımınowanıa początkowego obszaru pracy ze stałym momentem, co ułatwia ruszanie $\mathrm{z}$ miejsca składu o dużym obciążeniu. W takim przypadku wielkość momentu zmniejsza się wykładniczo, wraz ze wzrostem prędkości obrotowej silnika (częstotliwości zasilania), od jego wartości maksymalnej.

Wyznaczona charakterystyka świadczy o spełnieniu jednego z początkowych założeń projektowych, to jest pokonywania toru o znacznym kącie nachylenia $p$ [\%], co udało się osiagnąć dzięki wysokiej wartości sił trakcyjnych oraz przyczepności. Pierwsze z nich uzyskano w wyniku zastosowania silników wysokiej mocy $(280 \mathrm{~kW})$ oraz przekładni mechanicznej o wysokim przełożeniu. Z kolei drugie są efektem wysokiego stosunku liczby osi napędnych do tocznych (wysoka wartość nacisku napędnego) oraz osłony szyn przed warunkami atmosferycznymi w belce jezdnej i wiążącej się z tym stosunkowo wysokiej wartości statycznego współczynnika przyczepności. Przytoczoną charakterystykę wyznaczono dla pojazdu w pełni obciazżonego. W praktyce eksploatacyjnej sytuacja tego typu jest niezmiernie rzadka, a większość kursów odbywa się przy zaledwie połowie wypełnienia składu. Wraz ze spadkiem całkowitej masy pojazdu, zmniejszeniu ulegają również siły przyczepności i opory ruchu, co sumarycznie przekłada się na nieznaczny wzrost wartości maksymalnego nachylenia toru. Ponadto pojawia się wtedy znaczna nadwyżka sił trakcyjnych w stosunku do sił przyczepności, a więc w celu nie dopuszczenia do nadmiernego poślizgu zestawów kołowych, zastosowano układ antypoślizgowy.

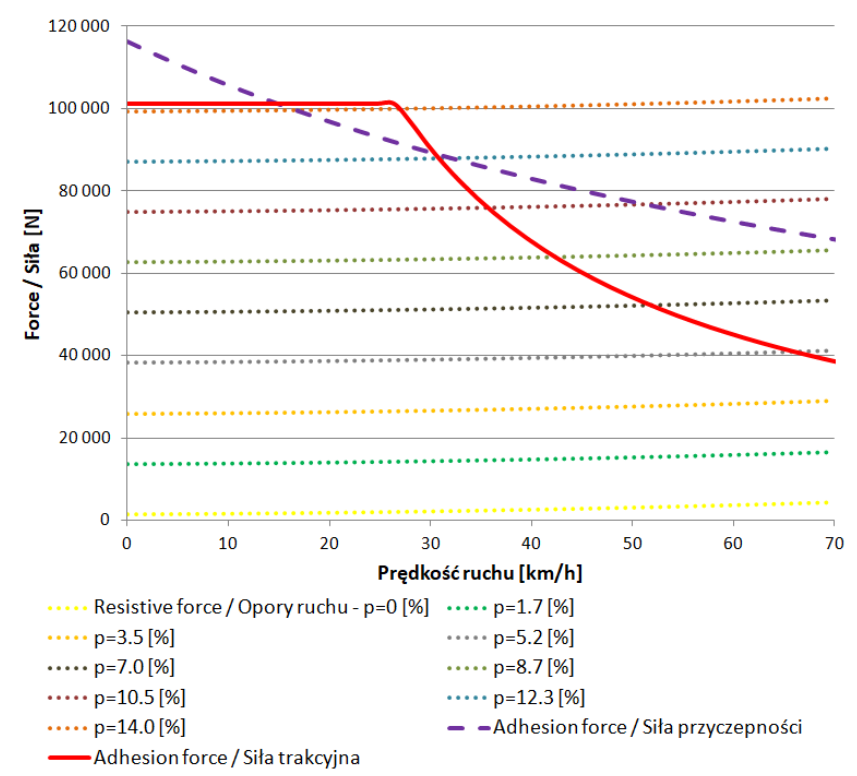

Fig. 3. Vehicle traction characteristic [5]

Rys. 3. Charakterystyka trakcyjna pojazdu [5] 
Obviously, the maximal acceleration value is limited by adhesion forces represented on the graph by dashed curve (Fig. 4), determined according to Newton's second law of motion.

Comparing the obtained values for a fully loaded vehicle with the starting and finally acceleration for metro vehicles $\left(0.8-1.2 \mathrm{~m} / \mathrm{s}^{2}\right.$ and $0.08-0.15 \mathrm{~m} / \mathrm{s}^{2}$ [4], respectively) and EMU $\left(0.6-0.8 \mathrm{~m} / \mathrm{s}^{2}\right.$ and $0.05-$ $0.07 \mathrm{~m} / \mathrm{s}^{2}$ [4]), it can be concluded that the obtained dynamic properties are sufficient.

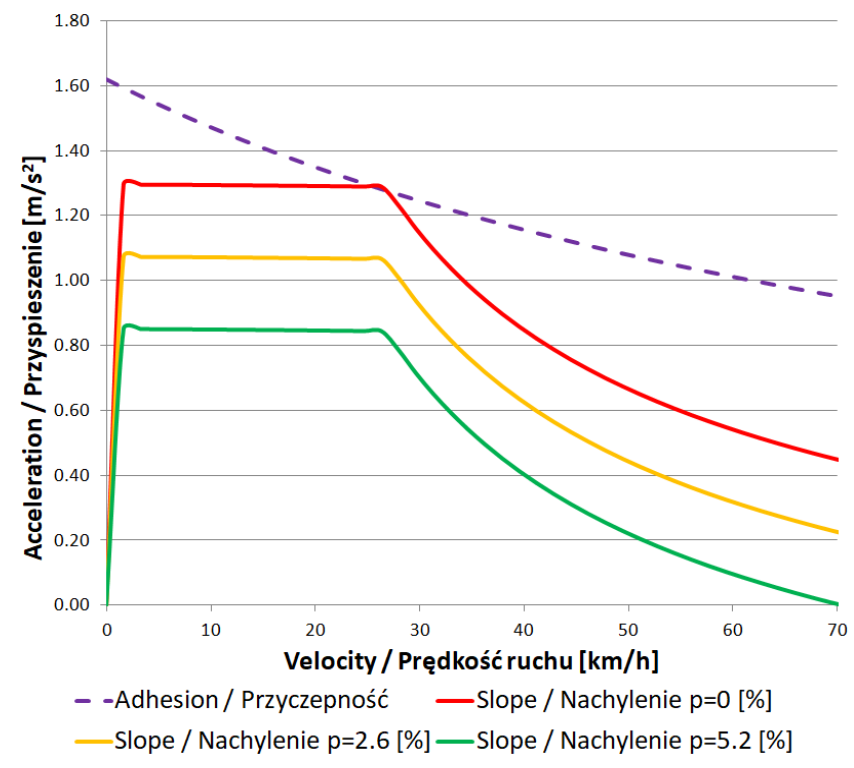

Fig. 4. Vehicle dynamics (acceleration) capabilities [5] Rys. 4. Parametry dynamiczne pojazdu [5]

\subsection{Braking system}

In the calculations performed in this subsection, the following quantities were used:

- total number of rail brake drag shoes $-1_{\mathrm{HS}}=6$ (two in every bogie);

- total number of friction rings of the vehicle's disc brake $-1_{\mathrm{HT}}=12$ (two rings are mounted on every wheel);

- number of friction surfaces $-\mathrm{n}=2$;

- radius of the action of the friction force $\mathrm{R}_{\mathrm{THT}}=0.2325 \mathrm{~m}$;

- pressure force of the friction lining of the disc brake - $\mathrm{Q}_{\text {DHT }}[\mathrm{N}]$ (its maximum value results from the permissible unit pressure of the friction lining);

- contact pressure of the rail brake drag shoe $\mathrm{Q}_{\mathrm{DHS}}=36000 \mathrm{~N}$ (being a function of its length, assuming $72 \mathrm{kN} / \mathrm{m}$ according to [9]);

- friction coefficient of disc brake lining $-\mu_{\mathrm{HT}}=0.35$ (suitable for FR20H.2 lining, according to [10]);

- coefficient of friction of a rail brake shoe $-\mu_{\mathrm{HS}}[-]$, the value of which changes as a function of speed according to the Krawiecki formula: [4]

$$
\mu_{H S}=\mu_{0} \cdot \frac{3,6 \cdot v+100}{1,8 \cdot v+100}
$$

Istotnym parametrem ruchowym składu komunikacji miejskiej, jest jego odpowiednia dynamika, niezbędna przy dużej liczbie rozruchów i hamowań. W celu oceny możliwości dynamicznych pojazdu posłużono się wartością jego przyspieszenia, wyznaczoną według: [4]

$$
a=\frac{1}{\gamma \cdot m} \cdot\left(\frac{s \cdot N_{s i l} \cdot \eta_{c}}{v}-W\right)
$$

Oczywiście wartość maksymalnego przyspieszenia ograniczona jest siłami przyczepności, które reprezentuje na wykresie przerywana krzywa (rys. 4), wyznaczona zgodnie z drugą zasadą dynamiki Newtona. Porównując uzyskane wartości dla w pełni obciążonego pojazdu z przyspieszeniami początku i końca rozruchu dla pojazdów metra (odpowiednio $0,8-1,2 \mathrm{~m} / \mathrm{s}^{2}$ i $0,08-0,15 \mathrm{~m} / \mathrm{s}^{2}$ [4]) oraz EZT $\left(0,6-0,8 \mathrm{~m} / \mathrm{s}^{2}\right.$ i 0,05 $\left.-0,07 \mathrm{~m} / \mathrm{s}^{2}[4]\right)$, można stwierdzić, że uzyskane własności dynamiczne są wystarczające.

\subsection{Układ hamulcowy}

$\mathrm{W}$ wykonanych $\mathrm{w}$ niniejszym podrozdziale obliczeniach posłużono się następującymi wielkościami:

- całkowita liczba płóz hamulca szynowego $-1_{\mathrm{HS}}=6$ (po dwie w każdym wózku);

- całkowita liczba pierścieni ciernych hamulca tarczowego pojazdu $-1_{\mathrm{HT}}=12$ (na każdym kole zamocowane są dwa pierścienie);

- liczba powierzchni tarcia $-\mathrm{n}=2$;

- $\quad$ promień działania siły tarcia $-\mathrm{R}_{\mathrm{THT}}=0,2325 \mathrm{~m}$;

- siła docisku okładziny ciernej hamulca tarczowego - $\mathrm{Q}_{\mathrm{DHT}}[\mathrm{N}]$ (jej maksymalna wartość wynika z dopuszczalnego nacisku jednostkowego okładziny ciernej);

- siła docisku płozy hamulca szynowego $\mathrm{Q}_{\mathrm{DHS}}=36000 \mathrm{~N}$ (będąca funkcją jej długości, przy założeniu $72 \mathrm{kN} / \mathrm{m}$ według [9]);

- współczynnik tarcia okładziny ciernej hamulca tarczowego $-\mu_{\mathrm{HT}}=0,35$ (odpowiedni dla okładziny FR20H.2, zgodnie z [10]);

- $\quad$ współczynnik tarcia płozy hamulca szynowego $\mu_{\mathrm{HS}}[-]$, którego wartość zmienia się $\mathrm{w}$ funkcji prędkości zgodnie ze wzorem Krawieckiego: [4]

$$
\mu_{H S}=\mu_{0} \cdot \frac{3,6 \cdot v+100}{1,8 \cdot v+100}
$$

gdzie założono wartość początkowego współczynnika tarcia $\mu_{0}=0,37$, tak aby uzyskać średni współczynnik tarcia równy 0,2 ; który przyjęto $\mathrm{w}$ obliczeniach hamulca szynowego w [11].

W powyższym zestawieniu nie uwzględniono symboli wykorzystanych przy wyznaczeniu charakterystyki trakcyjnej. W pojeździe zastosowano następujące rodzaje hamulców:

- hamulec elektrodynamiczny (ED) z rekuperacją energii w zasobnikach pokładowych - baterie superkondensatorów lub poprzez zwrot do sieci (pod 
The value of the initial coefficient of friction was established as $\mu_{0}=0.37$ to achieve the average coefficient of friction equal to 0.2 which was used in the calculations of the rail brake in [11].

The set above does not take into account the symbols used to determine the traction characteristic. The vehicle has the following types of brakes:

- electrodynamic brake (ED) with energy recuperation in vehicle storage units - supercapacitors batteries or by return to the network (provided that there is another vehicle with adequate energy demand on the same section). When energy recuperation is impossible, electrical energy is lost in the form of heat on the braking resistors. This type of brake is characterized by: no frictional wear, generation of braking force only on powered wheelsets and low efficiency at low speeds, which means that it must cooperate with another type of brake, but at the same time it should provide the highest possible percentage of the total braking power. The braking force was calculated according to:

$$
F_{H E D}=\frac{s \cdot N_{s i l}}{v}
$$

the motor power is constant in the area of constant power operation and varies according to the multiplication of the torque and the rotational speed in the area of the constant moment.

- disc brake which is an active direct electropneumatic brake in which the braking force is generated as a result of pressing the friction lining against friction ring. Its value was calculated according to:

$$
F_{T H T}=\frac{Q_{D H T} \cdot R_{T H T} \cdot \mu_{H T}}{R_{K}} \cdot n \cdot l_{H T}
$$

The parameters of the selected friction lining enable the realisation of the full braking power using only disc brake. This power is practically limited by the adhesion forces at the wheel-rail contact.

- tram-type electromagnetic rail brake (independent brake drag shoes are elastically suspended in the bogie frame), the braking force of which, generated by pressing its drag shoe against the rail surface, was calculated in accordance to:

$$
F_{H H S}=Q_{D H S} \cdot \mu_{H S} \cdot l_{H S}
$$

This value isn't restricted by wheel-rail contact adhesion phenomena.

The disc brake can be controlled by:

- BCU (Brake Control Unit) controller which is a part of the microprocessor control system of the vehicle (Fig. 5 - the diagram was created based on [12]). This system consists of two CAN main lines which allow the transfer of information between individual controllers with the most important of them being connected to both networks. The superior function is performed by the VCU (Vehicle warunkiem znajdowania się innego pojazdu, wykazującego odpowiednie zapotrzebowanie energetyczne, na tym samym odcinku sekcyjnym). $\mathrm{W}$ momencie, gdy rekuperacja energii jest niemożliwa energia elektryczna zostaje wytracona $\mathrm{w}$ postaci ciepła na rezystorach hamowania. Hamulec tego typu charakteryzuje się: brakiem zużycia ciernego, wytwarzaniem siły hamującej jedynie na napędnych zestawach kołowych oraz małą efektywnością przy niskich prędkościach, przez co musi on współpracować z innym typem hamulca, ale jednocześnie powinien realizować możliwie największy procent całkowitej mocy hamowania. Siłę hamującą obliczono zgodnie z:

$$
F_{H E D}=\frac{s \cdot N_{s i l}}{v}
$$

przy czym moc silnika jest stała w obszarze pracy ze stałą moca, a zmienia się według iloczynu momentu i prędkości obrotowej, w obszarze stałego mementu.

- hamulec tarczowy (aktywny hamulec elektropneumatyczny, typu bezpośredniego) w którym sita hamowania jest generowana $\mathrm{w}$ wyniku docisku okładziny ciernej do pierścienia ciernego. Jej wartość została wyznaczona według:

$$
F_{T H T}=\frac{Q_{D H T} \cdot R_{T H T} \cdot \mu_{H T}}{R_{K}} \cdot n \cdot l_{H T}
$$

Parametry dobranej okładziny ciernej umożliwiaja realizację pełnej mocy hamowania roboczego, wyłącznie hamulcem tarczowym. Moc ta jest praktycznie ograniczona przez siły przyczepności na styku koła z szyną.

- elektromagnetyczny hamulec szynowy typu tramwajowego (niezależne płozy hamulca są podatnie zawieszone w ramie wózka), którego siłę hamowania, wytworzona poprzez docisk jego płozy do powierzchni szyny, obliczono zgodnie z:

$$
F_{H H S}=Q_{D H S} \cdot \mu_{H S} \cdot l_{H S}
$$

Sama jej wartość nie jest ograniczona zjawiskiem przyczepności na styku koło-szyna.

Sterowanie hamulcem tarczowym może być realizowane przez:

- sterownik BCU (z ang. Brake Control Unit) stanowi część mikroprocesorowego układu sterowania pojazdu (rys. 5. - schemat został opracowany w oparciu o [12]). Układ ten złożony jest $\mathrm{z}$ dwóch magistrali sieci CAN, pozwalających na przesyłanie informacji pomiędzy poszczególnymi sterownikami, przy czym najważniejsze $\mathrm{z}$ nich zostały podłączone do obu magistral. Funkcję nadrzędną sprawuje sterownik VCU (z ang. Vehicle Control Unit), realizujący odpowiednie algorytmy sterowania. Za pracę układu napędowego, zwłaszcza przetwornic częstotliwości, odpowiadają sterowniki trakcyjne. 
- Control Unit) controller which implements the appropriate control algorithms. Traction controllers are responsible for the operation of the propulsion system, especially frequency converters.

- an additional, independent electronic network.

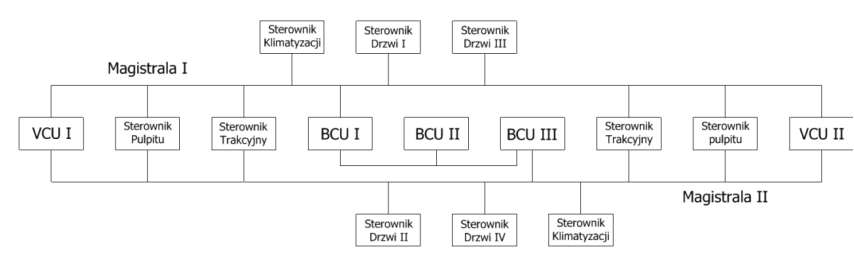

Fig. 5. Vehicle microprocessor system [5]

Rys. 5. Schemat mikroprocesorowej sieci pojazdu [5]

This way control redundancy was ensured, increasing the reliability of the braking system. In addition, a safety loop was used, the break of which causes the power supply to the emergency brake valve coil to be interrupted and braking with full power.

To evaluate the efficiency of the braking system, the average value of braking deceleration was used, during which the total energy of the vehicle (kinetic and potential) is lost by its motion resistance and forces generated by the braking system according to the equation: [13]

$$
E_{K}+E_{P}=\int_{0}^{S_{H}}\left(F_{H} \cdot d s\right)+\int_{0}^{S_{H}}\left(W_{z a s} \cdot d s\right)
$$

Assuming the average values of the braking force $\left(\mathrm{F}_{\mathrm{H}}\right)$ and basic resistance of motion $\left(\mathrm{W}_{\mathrm{zas}}\right)$, the above equation can be written as:

$$
E_{K}+E_{P}=F_{H} \cdot S_{H}+W_{z a s} \cdot S_{H}
$$

Then substituting for:

- kinetic energy

$$
E_{K}=\frac{\gamma \cdot m \cdot v^{2}}{2}
$$

- potential energy

$$
E_{P}=m \cdot g \cdot S_{H} \cdot \sin (\alpha)
$$

- braking distance

$$
S_{H}=\frac{v^{2}}{2 \cdot a_{H}}
$$

The final equation was oblamed:

$$
a_{H}=\frac{F_{H}+W_{z a s}-m \cdot g \cdot \sin (\alpha)}{\gamma \cdot m}
$$

Table 2 summarizes the average deceleration values calculated according to the above equation, taking into account: extremely different vehicle masses (empty and maximum mass), two different braking start speeds and different types of braking (the division was developed on the basis of the regulation of the minister of infrastructure regarding tram vehicles [14]), this is:

- service braking - enabling smooth speed regulation, is realized by cooperation of the ED brake with the disc brake (so-called blending), or only
- dodatkową, niezależną sieć elektroniczną.

W taki sposób została zapewniona redundancja sterowania, zwiększająca pewność działania układu hamulcowego. Oprócz tego wykorzystano pętlę bezpieczeństwa, której przerwanie powoduje zaprzestanie zasilania cewki zaworu hamowania nagłego $\mathrm{i}$ hamowanie $\mathrm{z}$ pełną moca.

Do oceny skuteczności układu hamulcowego posłużono się średnią wartością opóźnienia hamowania, w trakcie którego sumaryczna energia pojazdu (kinetyczna i potencjalna) wytracana jest przez jego opory ruchu i siły generowane przez układ hamulcowy, zgodnie z zależnością: [13]

$$
E_{K}+E_{P}=\int_{0}^{S_{H}}\left(F_{H} \cdot d s\right)+\int_{0}^{S_{H}}\left(W_{z a s} \cdot d s\right)
$$

Zakładając sreanıe wartosci sıły namujące $\left(\mathrm{H}_{\mathrm{H}}\right) 1$ zasadniczych oporów ruchu $\left(\mathrm{W}_{\text {zas }}\right)$, powyższe równanie można zapisać $\mathrm{w}$ postaci:

$$
E_{K}+E_{P}=F_{H} \cdot S_{H}+W_{z a s} \cdot S_{H}
$$

Następnie podstawiając za:

- energię kinetyczną

$$
E_{K}=\frac{\gamma \cdot m \cdot v^{2}}{2}
$$

- energię potencjalną

$$
E_{P}=m \cdot g \cdot S_{H} \cdot \sin (\alpha)
$$

- drogę hamowania

$$
S_{H}=\frac{v^{2}}{2 \cdot a_{H}}
$$

Uzyskano końcowe równanie:

$$
a_{H}=\frac{F_{H}+W_{z a s}-m \cdot g \cdot \sin (\alpha)}{\gamma \cdot m}
$$

Table 2 Vehicle braking capabilities Tabela 2 Parametry hamowania pojazdu

\begin{tabular}{|l|l|l|l|l|}
\hline \multirow{2}{*}{$\begin{array}{l}\text { Braking type / } \\
\text { Rodzaj hamo- } \\
\text { wania }\end{array}$} & \multicolumn{4}{|l|}{$\begin{array}{l}\text { Velocity of braking initiation / } \\
\text { Początkowa prędkość hamowania }\end{array}$} \\
\cline { 2 - 5 } $30 \mathrm{~km} / \mathrm{h}$ & \multicolumn{4}{|l|}{$\begin{array}{l}\text { Braking deceleration }\left[\mathrm{m} / \mathrm{s}^{2}\right] / \\
\text { Opóźnienie hamowania }\left[\mathrm{m} / \mathrm{s}^{2}\right]\end{array}$} \\
\cline { 2 - 5 } & $\begin{array}{l}\text { Empty / } \\
\text { Próżny }\end{array}$ & $\begin{array}{l}\text { Full / } \\
\text { Ładowny }\end{array}$ & $\begin{array}{l}\text { Empty / } \\
\text { Próżny }\end{array}$ & $\begin{array}{l}\text { Full / } \\
\text { Ładowny }\end{array}$ \\
\hline $\begin{array}{l}\text { Service / } \\
\text { Robocze }\end{array}$ & 2.4943 & 2.4863 & 2.1805 & 2.1604 \\
\hline $\begin{array}{l}\text { Emergency / } \\
\text { Awaryjne }\end{array}$ & 1.1344 & 0.6918 & 0.9119 & 0.5577 \\
\hline $\begin{array}{l}\text { Safety / } \\
\text { Bezpieczeństwa }\end{array}$ & 2.4943 & 2.4863 & 2.1805 & 2.1604 \\
\hline $\begin{array}{l}\text { Sudden / } \\
\text { Nagłe }\end{array}$ & 3.6009 & 3.1584 & 3.0420 & 2.6879 \\
\hline
\end{tabular}

W tabeli 2 zestawiono obliczone, według powyższego równania średnie wartości opóźnienia, biorąc pod uwagę: skrajnie różne masy pojazdu (masę własną i maksymalna), dwie różne prędkości rozpoczęcia hamowania oraz różne jego rodzaje (podział opracowano na podstawie rozporządzenia ministra infrastruktury 
- by the disc brake. The degree of use of each type of brake is controlled by the BCU controller;

- emergency braking - allows the vehicle to be stopped in the event of a complete failure of the service brake and is performed by the rail brake;

- safety braking - braking implemented by the passenger and performed by the ED and disc brake;

- sudden braking - ensuring the maximum value of deceleration, assumes simultaneous use of all types of brakes.

In addition, a parking brake can be distinguished, which immobilizes an already stopped vehicle, and it is implemented by spring brakes installed in every second disc brake calliper (one per wheelset). Moreover, the calculations took into account, if necessary, the limitation of the deceleration value related to the adhesion phenomenon.

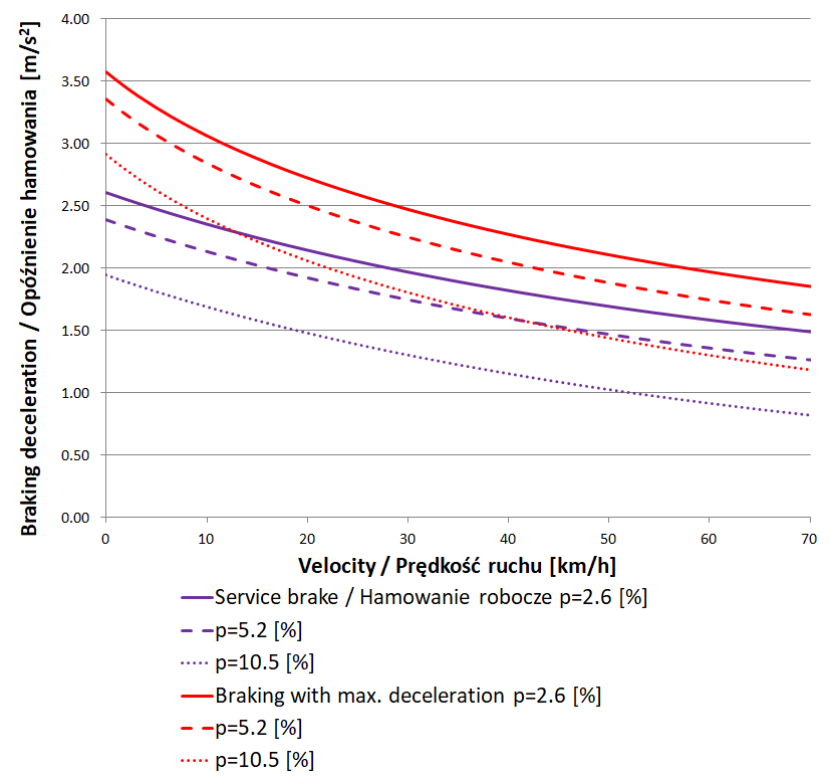

Fig. 6. Vehicle deceleration depending of the velocity [5] Rys. 6. Przebieg opóźnienia hamowania w funkcji prędkości [5]

The values presented in Table 2 [5] can be compared with those required in the Journal of Laws No. 2011 No. 65, item. 343 [14] for a tram (manufactured after $01.01 .2005)$ empty on a horizontal track, where the braking deceleration must be greater than or at least equal to:

- $\quad 3.0 \mathrm{~m} / \mathrm{s}^{2}-$ for sudden braking;

- $1.4 \mathrm{~m} / \mathrm{s}^{2}$ - for service braking;

- $1.8 \mathrm{~m} / \mathrm{s}^{2}$ - for safety braking.

The obtained deceleration values meet the above guidelines. However, taking into account the design assumptions and the traction capabilities of the vehicle, the curse and value of braking deceleration curves were determined depending on its type, track gradient and speed (Fig. 6). The decreasing nature of the presented curves is mainly due to the decrease in the value of adhesion forces with speed.

The average value of deceleration for the vehicle with the maximum load, sliding on the track with a gradient odnośnie pojazdów tramwajowych [14]), to jest:

- hamowanie robocze - umożliwiające płynną regulację prędkości, jest realizowane poprzez współpracę hamulca ED z hamulcem tarczowym (tzw. blending), lub wyłącznie przez hamulec tarczowy. Stopień wykorzystania poszczególnych typów hamulców kontroluje sterownik BCU;

- hamowanie awaryjne - pozwala na zatrzymanie pojazdu w przypadku całkowitej niesprawności hamulca roboczego i jest realizowane przez hamulec szynowy;

- hamowanie bezpieczeństwa - hamowanie wdrożone przez pasażera, a realizowane przez hamulec ED i tarczowy;

- hamowanie nagłe - zapewniające maksymalną wartość opóźnienia hamowania, zakłada jednoczesne wykorzystanie wszystkich typów hamulców.

Dodatkowo można wyróżnić hamulec postojowy, unieruchamiający już zatrzymany pojazd, a realizowany poprzez hamulce sprężynowe zabudowane w co drugim zacisku hamulca tarczowego (po jednym na zestaw kołowy). Ponadto w obliczeniach uwzględniono, tam gdzie to konieczne, ograniczenie wartości opóźnienia związane ze zjawiskiem przyczepności.

Zestawione $\mathrm{w}$ tabeli 2 [5] wartości można porównać $\mathrm{z}$ wymaganiami zawartymi w Dz.U. $2011 \mathrm{nr} 65$ poz. 343 [14] dla tramwaju (wyprodukowanego po 01.01.2005) próżnego na torze poziomym, gdzie opóźnienie hamowania musi być większe, lub co najmniej równe:

- $\quad 3,0 \mathrm{~m} / \mathrm{s}^{2}$ - dla hamowania nagłego;

- $1,4 \mathrm{~m} / \mathrm{s}^{2}$ - dla hamowania roboczego;

- $1,8 \mathrm{~m} / \mathrm{s}^{2}$ - dla hamowania bezpieczeństwa.

Uzyskane wartości opóźnień spełniają powyższe wytyczne. Jednak zważywszy na założenia projektowe i możliwości trakcyjne pojazdu, wyznaczono przebieg oraz wartości opóźnienia hamowania w zależności od: jego rodzaju, stopnia nachylenia toru oraz prędkości (rys. 6). Malejacy charakter zaprezentowanych krzywych jest w głównej mierze spowodowany spadkiem wartości sił przyczepności wraz z prędkością.

Średnia wartość opóźnienia hamowania dla pojazdu o maksymalnym obciążeniu, zjeżdżającym po torze o nachyleniu $10,5 \%$ przy hamowaniu roboczym wynosi $1,27 \mathrm{~m} / \mathrm{s}^{2}$. Wartość ta jest o $0,13 \mathrm{~m} / \mathrm{s}^{2}$ mniejsza od tej wymaganej dla tramwajów przy nieporównywalnie mniej wymagających warunkach, co świadczy o odpowiednich parametrach układu hamulcowego.

\section{PODSUMOWANIE}

Przedstawiona w artykule metodyka obliczeniowa pozwoliła na wyznaczenie podstawowych parametrów trakcyjnych pojazdu, w tym również wartości liczbowych przyspieszenia oraz opóźnienia hamowania. Wyniki obliczeń, zaprezentowane w postaci wykresów i tabel, pozwoliły stwierdzić, że opracowany przez autorów układ napędowy oraz hamulcowy, spełniaja założenia projektowe (pokonywanie toru o znacznym 
of $10.5 \%$ with service braking is $1.27 \mathrm{~m} / \mathrm{s}^{2}$. This value is $0.13 \mathrm{~m} / \mathrm{s}^{2}$ lower than that required for trams in incomparably less demanding conditions, which proves the appropriate parameters of the braking system.

\section{SUMMARY}

Thanks to calculation methodology which was presented in the article, it is possible to obtain vehicle traction parameters with exact values of acceleration and deceleration. Calculation results were presented in tables and graphs, which allowed to make conclusion that designed propulsion and braking systems fulfils earlier assumptions, especially ability to run on a track with significant slope angle. Moreover, thanks to those systems, the vehicle could be operated safely. This conclusion was based on the requirements from tram norms, because appropriate norms for monorails vehicles, aren't available. In addition there is a significant advantage of the solution in which the rails are inside the guideway beam, which results in obtaining stable and optimal working conditions. However, when interpreting the combined results, one should take into account the conceptual nature of the vehicle (including its systems), as well as the simplifications and assumptions adopted in the calculations. The methodology itself can be used to evaluate the movement parameters of other, including conventional, rail vehicles. kącie nachylenia). Ponadto, dzięki nim pojazd może podlegać bezpiecznej eksploatacji, co można wnioskować jedynie w oparciu o normy tramwajowe $\mathrm{z}$ racji faktu, że odpowiednie przepisy dla kolei jednoszynowych praktycznie nie są dostępne. Dodatkowo, uwidacznia się tu wyraźna przewaga rozwiązania, w którym szyny są osłonięte wewnątrz belki jezdnej, czego skutkiem jest uzyskanie stabilnych i optymalnych warunków pracy. Interpretując zestawione wyniki należy mieć na uwadze koncepcyjny charakter pojazdu (w tym jego układów), jak również przyjęte w obliczeniach uproszczenia i założenia. Sama metodologia może być wykorzystana do oceny parametrów ruchowych innych, w tym konwencjonalnych, pojazdów szynowych.

1 Kuczyk M., Jędrzejewski P., Zatuski P.: Koncepcja miejskiego pojazdu kolei podwieszane (The concept of suspended rail vehicle); Pojazdy Szynowe 2021;(2):52-66 (DOI: https://doi.org/10.53502/RAIL-139982).

2 Kikuchi S., Onaka A.: Monorail development and application in Japan; Jurnal of Advanced Transportation vol 22, Issue 1/p.17-38 (DOI: https://doi.org/10.1002/atr.5670220103)

3 Dynamic analysis on suspended monorail vehicles passing through turnouts; Qiang Guo et al 2018 IOP Conf. Ser.: Mater. Sci. Eng. 439042078 (DOI: 10.1088/1757-899X/439/4/042078)

4 Madej J.: Teoria ruchu pojazdów szynowych; Oficyna Wydawnicza Politechniki Warszawskiej, Warszawa 2012.

5 Jędrzejewski P., Kuczyk M.: Koncepcja wagonu silnikowego kolei podwieszanej; praca magisterska, Gdańsk 2020.

6. Dudzik M.: Metodyka obliczania największego możliwego przyspieszenia ograniczonego warunkiem przyczepności dla pojazdu trakcyjnego na przykładzie pojazdu Flirt ED 160 firmy Stadler; PTiL 3/2018 (43) (DOI: 10.18276/ptl.2018.43-02).

7. Lipiński L., Miszewski M.: Wyznaczenie charakterystyk trakcyjnych pojazdów kolejowych z asynchronicznymi napędami trakcyjnymi; Zeszyty Problemowe - Maszyny Elektryczne $n r$ 1/2012 (94); artykut dostępny pod adresem: http://www.komel.katowice.pl/ZRODLA/FULL/94/ref 12.pdf(dostęp na dzień 21.09.21).

8. $\quad$ Skibicki J.: Pojazdy elektryczne część I; Wydawnictwo Politechniki Gdańskiej, Gdańsk 2010.

9. Broszura informacyjna firmy Knorr - Bremse: Magnetic track brakes - light rail vehicles; 2018; dostęna pod adressem: $\quad$ https://www.knorr-bremse.com/remote/media/documents/railvehicles/product_broschures/2018_2/ product/brake_systems/Magnetic_Track_Brakes_-_LRV_P-1269_EN.pdf(dostęp na dzień 21.09.21) .

10. Katalog firmy Frenoplast: Wagony pasazerskie i metro; wydanie 2 z dnia 16.08.2018; dostepny pod adresem: https://frimatrail-frenoplast.pl/wp-content/uploads/pdf/pasazerskie/Katalog-Frenoplast-pasazerskie-PL-2018.pdf (dostęp na dzień 21.09.21).

11. Piechowiak T.: Obliczenia hamulca wózka tramwajowego; Czasopismo techniczne Mechanika, 2012, R. 109, z. 7M; artykut dostęny pod adresem: https://repozytorium.biblos.pk.edu.pl/resources/31364 (dostęp na dzień 21.09.21)

12. Barna G., Durzyński Z.: Struktura rozproszonego systemu mikroprocesorowego sterowania zespołem trakcyjnym; Technika Transportu Szynowego $n r$ 3/2008, str. 36 - 43; artykut dostepny pod adresem: http://yadda.icm.edu.pl/yadda/element/bwmetal.element.baztech-article-BGPK-2072-7844 (dostęp na dzień 21.09.21)

13. Gunay M., Korkmaz M. E., Ozmew R.: An investigation on braking systems used In railway vehicles; Engineering Science and Technology, an International Journal, (DOI: https://doi.org/10.1016/j.jestch.2020.01.009).

14. Przepióra K., Szuberski P.: Badania układów hamulcowych pojazdów tramwajowych $w$ aspekcie homologacji typu tramwajów; Pojazdy Szynowe nr 2/2017, str. 52 - 61 (DOI: https://doi.org/10.53502/RAIL-138455). 